\title{
Charles Darwin: Some Bibliographical Problems and Textual Implications
}

\author{
Richard G. Landon
}

WHEN I WAS ASKED TO ADDRESS THIS MEETING OF THE BIBLIOGRAPHICAL Society of Canada on the subject of Charles Darwin, I wondered whether it was incumbent upon me to introduce what our national broadcasting system is pleased to call 'Canadian content.' To do so is difficult because Darwin, as far as I know, came no closer to Canada than the Azores, there are no early Canadian editions of any of his works, and Canada is not mentioned in any of his principal books. The theory of natural selection was no doubt discussed and debated in Canada and probably raised the same controversies it did elsewhere, but the citizens of Canada were apparently reticent about publishing their views. The only early Canadian piece of Darwiniana I have seen is a pamphlet produced by the Canadian News and Publishing Company of Toronto in I87I. It is titled The Fall of Man; or, The Loves of the Gorillas: A Popular Scientific Lecture upon the Darwinian Theory of Development by Sexual Selection and its author is designated as 'A Learned Gorilla.' It is one of many reactions to the Descent of Man, published in the same year, and assumes the form of a lecture in the jungle by a gorilla. The author was Richard Grant White, an American journalist. Darwin also contributed to the Testimonials for T.H. Huxley when Huxley applied for the Chair of Natural History at the University of Toronto in $185 \mathrm{I}$. Despite the enthusiastic testimony of Huxley's colleagues, the post was awarded to William Hincks, who happened to be the brother of Sir Francis Hincks, in I85 I Prime Minister of the Province of Canada.

The Canadian connection with Darwin that I would, however, like to describe briefly, as what I have to say concerning bibliographical and textual problems is founded on it, is the extensive Darwin collection at the Thomas Fisher Rare Book Library in the University of Toronto. ${ }^{1}$ This collection has been based on the collection of Richard Freeman, Darwin's bibliographer, ${ }^{2}$ acquired in 1968 , to which numerous additions continue to be made. At first glance a 'complete' collection of Darwin would appear to involve relatively few items. There are his sixteen books (twenty, if one counts four longish pamphlets), his contributions to nine books by other authors, and a number of small pamphlets and broadsheets wholly or partly written by him. The total 
number of titles up to the year of his death, I882, is forty-two. In addition Darwin contributed one hundred and sixty-six papers and notes to periodicals. Since his death several previously unpublished manuscripts have appeared, most notably the series of notebooks compiled by him during and shortly after the Beagle voyage and his letters and autobiography. The total, even with the addition of translations and American editions, is still not very large and would not seem to present many serious bibliographical difficulties. That there are a whole series of bibliographical complexities is due to the practice of John Murray, Darwin's principal publisher, of issuing only a few copies of a work (usually two thousand or less) at any one time. These impressions Murray called 'thousands,' and title pages and preliminaries were altered for each. Not only preliminary matter was altered, however. Darwin was able to make small revisions between thousands even when stereo plates were used for printing, and new, extensively revised, editions are sometimes indicated by the 'thousand' number. Origin of Species perhaps provides the best example of the textual importance of such bibliographical peculiarities.

Darwin had intended to publish what he referred to as a 'big book' on the transmutation of species, based on the huge amount of information he had collected during the Beagle voyage and after his return to England. His 'bolt from the blue,' in the form of a letter from Alfred Russell Wallace, appeared on June I 8 th, I858, and forced him to begin work on Origin itself. Their joint paper, 'On the Tendency of Species to Form Varieties,' was communicated to the Linnean Society on July ist, I 858 , by Sir Joseph Hooker and Sir Charles Lyell and was published in the Society's Journal on August 3oth. On the Origin of Species by Means of Natural Selection, or the Preservation of Favoured Races in the Struggle for Life, as the first edition is called, was published on November 24 th, I859, in an edition of I, 250 copies, all of which, it is often said, were sold on the first day. This appealing myth cannot possibly be true, but the book, for which a large public was eagerly waiting, certainly sold very quickly. There is only one issue of the first edition, although two variants of the binding case and three variants of the inserted advertisements (dated June I859) have been identified. Its format is usually described as duodecimo, and it is indeed gathered in twelves; however, it is really an octavo imposed in crown sheets and a half. The second edition, for which Darwin intended to make only a few corrections, appeared on January 7 th, I860 (Freeman does record two copies dated I859), in a print run of 3,000 copies. Its title page, however, designates it only as 'fifth thousand' (i.e., I,250 copies plus 3,000 equals 4,250 ) and Darwin considered it essentially a reprint in which the printers would use his corrected copy of the first as yet another revise and would only reset lines and paragraphs when necessary. The 'few revisions,' however, add up to 9 sentences dropped, 483 rewritten or repunctuated, and 30 added. No chapter was left exactly as it was in the first, 
and particularly for textual purposes this fifth thousand must be regarded as a genuine edition.

The third edition, for which Darwin intended 'additions, which I have made in hopes of making my many rather stupid reviewers at least understand what is meant, ${ }^{\prime 3}$ was published in April I86I. It is designated on its title page 'third edition, seventh thousand' and 2,000 copies were printed. In it 33 sentences were dropped, 6I7 altered, and 266 added, and it contained a table of 'Additions and Corrections to the Second and Third Editions' (presumably to assist the reviewers) and the 'Historical Sketch of the Recent Progress of Opinion on the Origin of Species.' This 'Sketch' was written to satisfy complaints that Darwin had not sufficiently acknowledged his predecessors regarding the general theory of evolution and continued to be included in subsequent editions.

The fourth edition of I, 500 copies was published in I 866 and was called the eighth thousand. It was again extensively altered, 96 sentences being dropped, I,073 rewritten, and 435 added. This edition lasted for two and one half years until the fifth edition, tenth thousand, appeared in August I869. Two thousand copies were printed of this most important edition, which uses for the first time Herbert Spencer's phrase 'survival of the fittest. ${ }^{4}$ The format was changed to octavo in eights and the design of the binding case was altered. The revisions ran through the whole book: 178 sentences were dropped, I,770 were altered, and 227 were added.

The sixth edition, generally regarded as the final edition, appeared in February I872 and Murray's accounts show that 3,000 copies were printed. This total presumably includes the issue with 'eleventh thousand' on the title page and also that with 'twelfth thousand' issued in the same year. This was a 'popular edition' with smaller type and a cheaper case. The revisions continued with 63 sentences dropped, 1,669 rewritten, and 57I added. More importantly, a whole new chapter (VII) was added to refute the views of the Roman Catholic biologist St. George Mivart, and a 'glossary of the principal scientific terms' by W.S. Dallas was added. The title of the book was changed to The Origin of Species and, surprisingly, the word 'evolution' was used for the first time..$^{5}$ Later in the same year this edition was reprinted from the stereos as the thirteenth thousand, and again as the thirteenth thousand in I873, a total of 2,000 copies. The fifteenth thousand ( 1,500 copies) appeared in I875, the eighteenth thousand ( 1,250 copies) in 1876 , the twentieth thousand $(2,000$ copies $)$ in 1878 , the twenty-second thousand ( 2,000 copies $)$ in 1880 , and the twenty-fourth thousand (2,000 copies) in 1882 , the year of Darwin's death.

This possibly tedious recital of numbers is intended to establish a chronological sequence and to point out that the eighteenth thousand of 1876 is in fact the final text as Darwin left it. The changes between it and the sixth edition of 1872 are not extensive but are undoubtedly by Darwin himself. The 
hundreds of editions of Origin published during the past century are usually straight reprints of the I872 text. A scholarly edition of the work ought properly to include collation of the different issues of the sixth edition; the same principle applies to Darwin's other books.

American editions of Origin, published by Appleton of New York, must also be considered. There are four separate printings of 1860 , for instance, three of which have identical texts despite the phrase 'revised edition' that appears on one of them. The fourth, which is designated 'new edition, revised and augmented by the author,' is quite different, containing as it does a supplement of seven pages to the 'additions and alterations' and a brief form of the 'historical sketch' a year earlier than the first appearance of the full historical sketch in the third English edition.

The Darwin Collection at Toronto contains copies of all these editions, impressions, and issues and several variants of a less significant kind and attempts to provide the same kind of textual resource for all of Darwin's works. The rest of the collection is made up of Darwiniana: the works of predecessors mentioned in the historical sketch; the works of contemporaries such as Lyell, Hooker, and Huxley; the scientific works of the later figures who interested themselves in the implications of Darwin's theories; and the works of a general nature, mainly religious, that commented favourably and critically on the controversies raised by his work. Indeed, the basic controversy continues to this day and only last autumn I was handed a flyer on St. George Street in Toronto by someone dressed as a gorilla that advertised a debate on the truth of the theory of natural selection.

Having begun with the complex, but well documented example of Origin of Species, I would like to turn to one of Darwin's less scientifically significant publications, but probably his most popular work. This book is now generally known as the Voyage of the Beagle and its textual complexities begin with its title. It was first issued as the third volume of the Narrative of the Surveying Voyages of His Majesty's Ships Adventure and Beagle, between the Years 1826 and 1836: Describing their Examination of the Southern Shores of South America, and the Beagle's Circumnavigation of the Globe (London: Colburn, I839), edited by Captain Fitzroy. In this form Darwin's volume is called Journal and Remarks and was actually written and in print by early I 838 , but had to wait for the other volumes of the set to be completed. In I839 Darwin's work was also re-issued as a separate publication, allegedly because of its greater popularity in comparison with the other two volumes of technical narrative. The preliminary pages i to vi were cancelled and replaced with a title page that read Journal of Researches into the Geology and Natural History of the Various Countries Visited by H.M.S. Beagle, under the Command of Captain Fitzroy, R.N., from 1832 to 1836. The sheets of the text were those of the first issue. The third issue appeared in 1840 and is identical to the second 
NARRATIVE

ov $x$ six:

\section{SURVEYING VOYAGES}

OF KIS MAJESTY'S SKIPS

\section{ADVENTURE AND BEAGLE,}

nxrwxxk

TEE TEARS 1526 AND 1SS6,

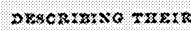

EXAMINATTON OF THE SOUTHERN SHORES

ox

SOUTH AMERICA,

AND

TEE EEAGLES CRRCCMXAVIGATION OF TER GLOBE.

IN Trees voutues.

VOX. TIT.

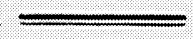

$20 \mathrm{NDO}$ :

gENRY COLBURN, GREAT MARLBOROUGH STREET.

7839 .

FIGURE I: Volume III of Fitzroy's Narrative (I839). 


\section{JOURNAL OF RESEARCHES}

InTo max

\section{GEOLOGY}

ANo

\section{NATURAL HISTORY

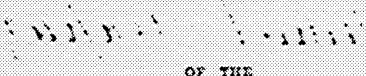 \\ of $7 x x$}

\section{VARIOUS COỴNRIIES}

VISITED BY E. M. S. BEAGLE, UNDER THE COMMAND OF CAPTAIN FITZROY, R.N.

FROM ISs2 TO 1886 .

BY

CHARLES DARWIN. EsQ., M.A. F.R.R.S.

SECRETARY TO TEZ GEOZOGZCAZ SOCIETY.

\section{IONDON:}

GENRY COLBURN, GREAT MARIBOROUGH STREET. 1889.

FIGURE 2: The separate 1839 issue of the Journal of Researches. 


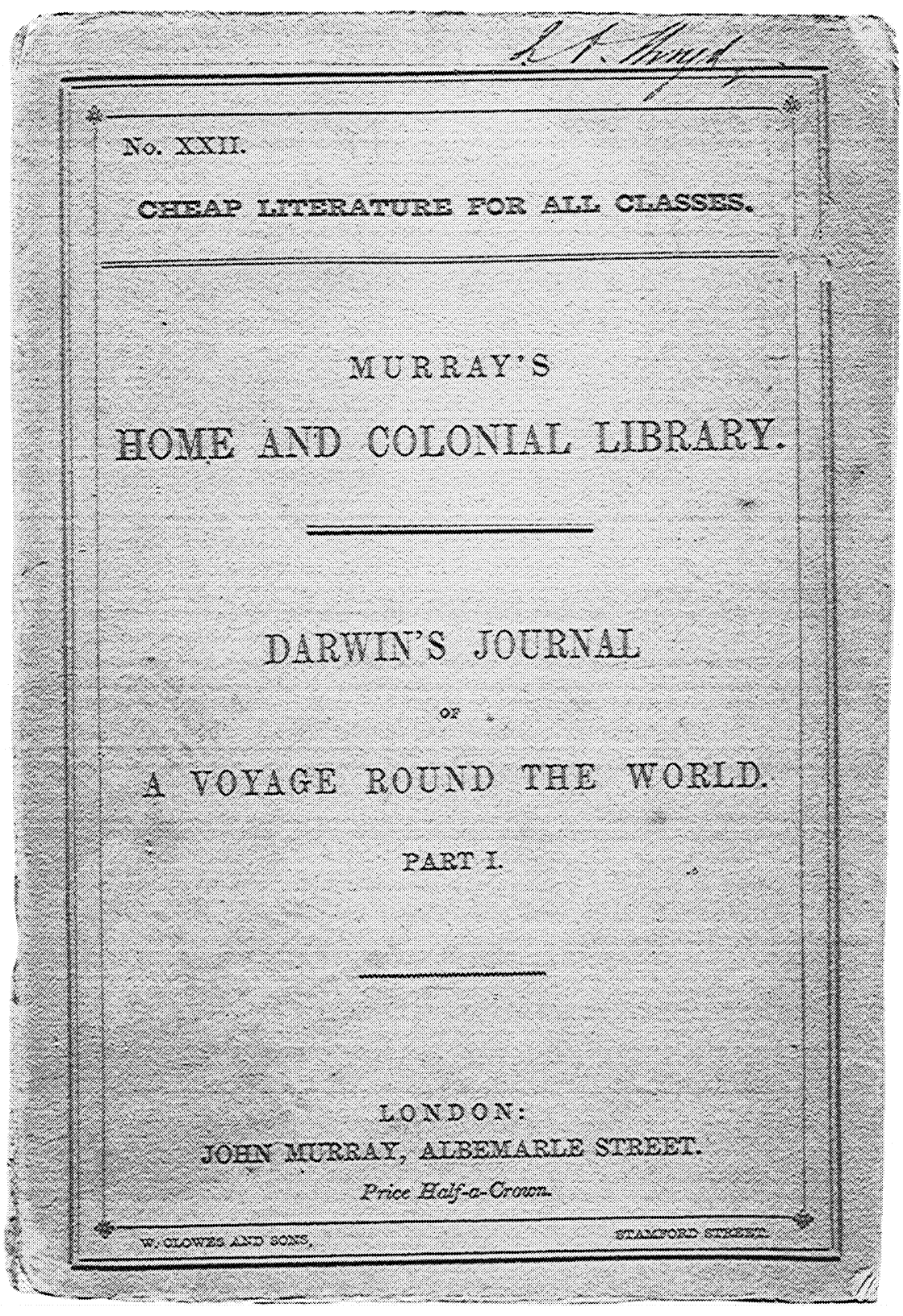

FIGURE 3: The wrapper of the 1845 part issue. 


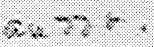

\section{JOURNAL OF RESEARCHES \\ XNO Nax}

\section{AATCRAL EISTORY AID GEOLOGY}

$$
\text { or } 2 x
$$

COTNTRIES VISTTED DTRING TEE VOYAGE OF

z. M. S. BEAGLE ROUND TEE WORLD,

$$
\text { axpas } 2 \pi x
$$

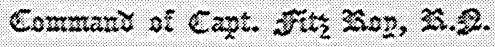

BX CHARLES DARWIN, M.A., F.RS.

SECOND EDITION, CORRECTED, MITE ADDITIONS.

$$
\text { LONDON: }
$$

JOEN MURRAY, ALBEMARLZ STREZT.

2845.

FIGURE 4: The title page of the 1845 part issue. 


\section{JOTRNAL OF RESEEARCHES}

\section{$2 \times 0$ retr: \\ TATURAL HISTORY AND GEOLOGY}

$$
\text { of } \operatorname{tax}
$$

COLAMRIES VISTMED DURATG TER VOTAGR OR E.XIS. BEAGLS ROTAD TEE WORID,

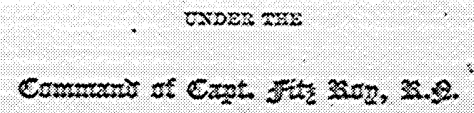

BX CEARLES DARWIX, YA, Z.RS.

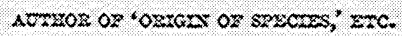

TENTE TEOTSLND.

$$
\text { LONDOX: }
$$

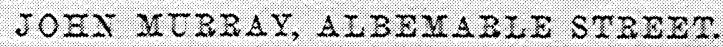
2850.

FIGURE 5: Journal of Researches, 'tenth thousand' (1860). 


\title{
JOURAAL OF RESEARCHES
}

$2 \times 1 \times 0:+x: 2$

\section{NATURAL HISTORY \& GEOLOGY}

\author{
of $: 2 x: 2$
}

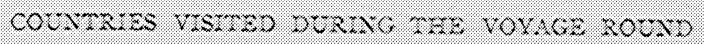

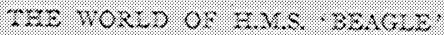

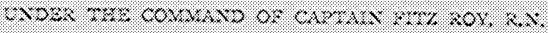

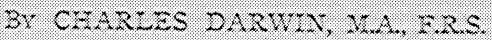

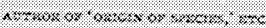

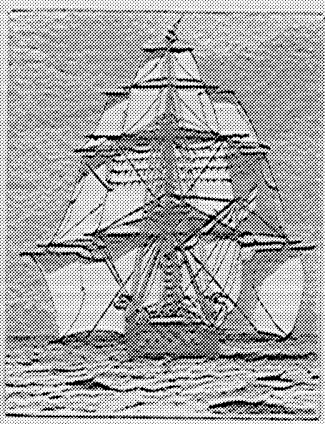

a. $1 \geq w=0.00$

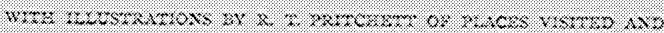

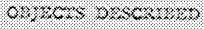

$$
2.0 \times 10 \times
$$

:

$: 890$

FIGURE 6: Murray's i 890 illustrated edition. 


\section{THE VOYAGE OF THE "BEAGLE"}

\section{Journal of Researches into the Natural}

History and Geology of the Countries Visited during the Voyage

Round the World of

$$
\text { H.M.S. "Beagle" }
$$

\section{By \\ CHARLES DARWIN \\ M.A., I.R.S.}

IONDON

THE AMAIGAMATED PRESS ITD

1905

FIGURE 7: The I905 Harmsworth Library edition. 
except that its conjugate title and half-title leaves have been reprinted. It also normally has its maps inserted in the text whereas the first two issues have them in a pocket in the rear cover.

The second edition was published in I 845 by John Murray / who bought the copyright for £I5O and became Darwin's principal publisher) in his Colonial and Home Library series. The text was extensively revised by Darwin, the number of words being reduced from approximately 224,000 to 213,000 and the maps being omitted entirely. There are also several variants of this edition, the first being a monthly issue in three parts, numbered XXII, XXIII, and XXIV in the series. (The only known copies of Parts I and 2 are in the Fisher Library collection; Part 3 has still to turn up.) The title of the work now undergoes its second change: Journal of Researches into the Natural History and Geology of the Countries Visited during the Voyage of the H.M.S. Beagle round the World, under the Command of Capt. FitzRoy, R.N. The significance of the reversal of 'natural history' and 'geology' in the title has been the subject of some speculation, and it is generally taken to indicate Darwin's increasing interest in his observations in natural history. ${ }^{6}$ It is certainly true that Darwin began the voyage with a primary interest in geology: his notebooks are filled with geological observations and his first published work, the so-called Letters on Geology, appeared while he was still on board the Beagle. The second issue of the 1845 edition of the Journal of Researches is in book form with the three contents leaves replaced by a single leaf. Stereo plates were then manufactured, from which several later printings were taken, the first probably appearing in $\mathrm{I} 848$ but still retaining 1845 on the title page. In 1852 it was again reprinted, this time with the correct date but described as a 'new edition,' although there are no textual changes. The I860 issue appears to be a new edition. It is no longer part of the Colonial and Home Library series in red cloth, but is bound in the same kind of green cloth used for Origin, and a postscript, dated February ist, I860, has been added by Darwin. Although the page height is nearly two centimetres greater than the previous issues and the whole appearance of the book is quite different, it is, in fact, printed from the stereos and is technically a new impression. It is called 'tenth thousand' and constitutes the final text as Darwin left it. In I870 another 'new edition' appeared, the only change being reset preliminaries, and the 'twelfth thousand' was published in I873. An I876 issue, however, is called the 'eleventh thousand,' presumably an error on Murray's part, as the fourteenth thousand is dated $\mathrm{r} 879$. The usual title is now preceded by 'A Naturalist's Voyage,' a phrase first used as a spine title on the I86o edition; this constitutes the third change of title. There followed a fifteenth thousand of I882, a sixteenth thousand of I884, a seventeenth thousand of I886, another so-called seventeenth thousand of 1888 , and finally the eighteenth thousand of I888. This is a new edition, completely reset, but - oddly - 
retaining the postscript in its original form. As the postscript contains three references to pages in the text, they now are all wrong. Ward Lock first issued the Journal of Researches, edited by G.T. Bettany, in their Minerva Library series in 1889 and reprinted it several times. The early Ward Lock impressions are confusingly all called 'editions' but have, so far as one can tell, no textual significance. In I 890 Murray's issued a new edition, reset, with the postscript finally incorporated as footnotes in the appropriate places in the text. In the same year Murray's published a splendid new edition on large paper with twelve plates, two maps, and ninety-three text woodcuts. They presumably did so in order to compete with Thomas Nelson, who had issued an illustrated edition in I888 (reprinted in I890). In I90I Murray's published another 'new edition' with sixteen plates and reprinted it several times. The many editions published since 1890 (Freeman lists over one hundred) normally reprint the text of 1845 , sometimes adding the postscript of I860. The final title, by which the book is generally known today, The Voyage of the Beagle, first appeared on the Harmsworth Library edition, published by Amalgamated Press in I905. In the United States the Journal of Researches (as I will continue to call it) was first published by Harper \& Brothers in two volumes in I846 and reprinted several times. It was based on Murray's I 845 text and never included the postscript. Appleton's, Darwin's normal American publisher, issued their first edition in I87I using the Murray stereos of I870, and there have, of course, been many American editions since.

This brief synopsis of the major editions of the Journal of Researches indicates the bibliographical complexity of the work. Before we examine the textual implications of these variants, it is necessary to describe another series of crucial documents that bear directly on the text. The most important of these is the manuscript diary, kept by Darwin during the voyage and published completely in facsimile in 1979 with an introduction by Prince Charles. The Diary is approximately 189,000 words in length and was used by Darwin as the basis for the Journal of Researches, supplemented with scientific detail drawn from a series of notebooks. These Darwin kept for the purpose of recording scientific data that he could accumulate only when he had the opportunity of closely examining his collections of specimens. The diary was edited for publication by Nora Barlow in 1933. A comparison of it with the 1839 and 1845 editions reveals extensive revisions between the three texts. The notebooks referred to earlier are continuing to be edited and published, and they constitute important textual sources for any understanding of the significance of the details in the Journal of Researches. Between 1960 and 1967 Sir Gavin de Beer and others brought out in six parts a series called the Darwin Notebooks on the Transmutation of Species, and recently the Red Notebook, containing Darwin's earliest notes on evolution, has been edited by S. Herbert. These notes form the basis of Darwin's developing theory of 
natural selection, and many of them result directly from his observations and collections from the voyage. There also exist twenty-four 'small notebooks,' excerpts from which are included in Lady Barlow's Charles Darwin and the Voyage of the Beagle (1945). These pocket-size books were actually carried by Darwin in South America, and fourteen of them deal with his inland travels. The entries are very brief indeed and were normally expanded considerably in the Diary. The Diary entries, in turn, were rewritten for the first edition of the published Journal and often revised for the second. An example demonstrates the process. Late in 1832 the Beagle reached Tierra del Fuego and FitzRoy began to chart the intricate channels of the Straits of Magellen. Darwin was fascinated by the spectacular glaciers and vividly records a near-fatal incident involving one in the Beagle Channel. In his small notebook the entry for January 29, 1833, reads (in part),

Scenery very retired - many glaciers, uninhabited, beryl blue, most beautiful, contrasted with snow. Glacier: cliff to sea about 40 feet, blue by transmitted and reflected light. Channel covered by small icebergs - miniature arctic ocean - Dinner, great waves, boat etc., pack up, grand sight. ${ }^{7}$

In the Diary this is expanded to:

The scenery becomes very grand.... In many places, magnificent glaciers extended from the mountains to the water's edge. I cannot imagine anything more beautiful than the beryl blue of these glaciers, especially when contrasted by the snow. The occurence of glaciers reaching to the water's edge $\&$ in summer, in Lat. $56^{\circ}$ is a most curious phenomenon: the same thing does not occur in Norway under Lat. $70^{\circ}$. From the number of small ice-bergs the channel represented in miniature the Arctic ocean. One of these glaciers placed us for a minute in most imminent peril. Whilst dining in a little bay about half a mile from one $\&$ admiring the beautiful colour of its vertical \& overhanging face, a large mass fell roaring into the water. Our boats were on the beach; we saw a great wave rushing onwards, $\&$ instantly it was evident how great was the chance of their being dashed into pieces. One of the seamen just got hold of the boat as the curling breaker reached it: he was knocked over $\&$ over but not hurt $\&$ most fortunately our boat received no damage. If they had been washed away, how dangerous would our lot have been, surrounded on all sides by hostile savages $\&$ deprived of all provisions. ${ }^{8}$

In the first edition of the Journal of Researches this description is divided between January 20th, I833, and the boat incident, which has been shifted to June 1834 , when, in fact, the Beagle did return to Tierra del Fuego and Darwin made some further observations on glaciers. The first section, under the correct date, reads,

The scenery here becomes even grander than before.... In many parts magnificent glaciers extended from the mountain side to the water's edge. It is scarcely possible to 
imagine anything more beautiful than the beryl-like blue of the glacier, and especially when contrasted with the dead white of an expanse of snow. As fragments fell from the glacier into the water, they floated away, and the channel with its icebergs represented in miniature the polar sea. ${ }^{9}$

The second part of the original passage, under June I834, tells the rest of the story:

On one occasion, the boats being hauled on shore, within the distance of half a mile from a glacier, we were admiring the perpendicular cliff of blue ice, and wishing that some more fragments would fall off, like those we saw floating on the water, at a distance of more than a mile from their source. At last, down came a mass with a roaring noise, and immediately we saw the smooth outline of a wave travelling towards us. The men ran down as quickly as they could to the boats; for the chance of their being dashed to pieces was evident. One of the seamen just caught hold of the bows, as the curling breaker reached it: he was knocked over and over but not hurt; and the boats, though thrice lifted on high and let fall again, received no damage. This was most fortunate for us, for we were a hundred miles distant from the ship, and we should have been left without provisions or fire-arms. ${ }^{10}$

In the second edition of $\mathrm{I} 845$ the text is again revised and reads,

In many parts, magnificent glaciers extend from the mountain side to the water's edge. It is scarcely possible to imagine any thing more beautiful than the beryl-like blue of these glaciers, and especially as contrasted with the dead white of the upper expanse of snow. The fragments which had fallen from the glacier into the water, were floating away, and the channel with its icebergs presented, for the space of a mile, a miniature likeness of the Polar Sea. The boats being hauled on shore at our dinnerhour, we were admiring from the distance of half a mile a perpendicular cliff of ice, and were wishing that some more fragments would fall. At last, down came a mass with a roaring noise, and immediately we saw the smooth outline of a wave travelling towards us. The men ran down as quickly as they could to the boats; for the chance of their being dashed to pieces was evident. One of the seamen just caught hold of the bows, as the curling breaker reached it: he was knocked over and over, but not hurt; and the boats, though thrice lifted on high and let fall again, received no damage. This was most fortunate for us, for we were a hundred miles distant from the ship, and we should have been left without provisions or fire-arms. ${ }^{11}$

A comparison of these four versions of the same passage demonstrates, first of all, Darwin's method of expanding and revising his work. His development of a literary style, a subject upon which he commented in letters, is also, incidentally, indicated. Lady Barlow estimated that, excepting the brief entries in the small notebooks, an overall comparison of the three texts would reveal that one-third of the Diary was omitted entirely from the first and second editions of the Journal of Researches although its total length is much 
shorter: 189,000 words in the Diary, 224,000 words in the first edition, and 213,000 words in the second. The rest of the text was added from the large notebooks of scientific observations which Darwin kept separately.

Given then the bibliographical complexities of the Journal of Researches and some indication of its textual history, what editorial principles ought to be applied when seeking to establish a scholarly, critical text? The principles promulgated by Greg, Bowers, Thorpe, and other textual scholars apply, in the main, to works of literature, and most of the examples cited to illustrate the effective application of these principles are drawn from the great corpus of English literature from the Renaissance to the present. Darwin was not a literary figure; he wrote no poems, plays, or novels. Yet the revisions he made in successive editions of his books have at least as much significance as the variant endings of Great Expectations or the successive and extensive revisions of Pamela.

The three basic questions asked by the editors of the Toronto edition of the Collected Works of John Stuart Mill, an author whose editorial practices bear some resemblance to Darwin's, may perhaps be relevant. ${ }^{12}$ First: Which text best represents what Mill wrote? Second: Which text represents Mill at his best? and Third: Which text did Mill think best? It might also be useful to consider the question of versions and texts; that is, the difference between the versions of a work and the texts of a particular version. For Mill the answer to the third question was that for all of his major works he preferred the final edition over any earlier one. The second question is more difficult, involving as it does the exercise of informed critical and aesthetic judgment-judgment that is properly within the province of a textual editor despite the existence of literary criticism. The Mill editors found that they could not definitively answer the question in a general sense, but could say that Mill's revisions resulted in successive texts, not in different versions; thus they concluded that they had no sufficient grounds for rejecting, as copy-text, the last edition known to have been revised by the author. The primary question concerning what represents most nearly what the author wrote is the most important. For Darwin, as for Mill, the question of substantive variants is easily answered. Any edition, whatever copy-text is chosen, must take account of and note substantives. It was the principle involving the treatment of accidentals which Greg emphasized and which has been much reiterated. Essentially that principle states that the further an editor departs from the author's manuscript the further he or she departs from the author's intention, and the decision of the Mill editors is here interesting and instructive. They reject the principle of first edition for accidentals on the grounds that the normalized spelling and punctuation of the revised editions, though admittedly the result of actions taken both by Mill and by the printer, are given sufficient authority by Mill's approval of them and that anomalies that might be discovered 
through detailed machine collation are, in Mill's case, relatively unimportant. Thus the Toronto Mill edition is textually founded on the last editions published in the author's lifetime.

How might one apply this practical experience (here stated in a much over-simplified way) to Darwin's works and, specifically, to the Journal of Researches? First, the question of versions and texts. It is clear, I think, that there are essentially two published editions of the work, the 1839 first and the I 845 second, although the I 860 tenth thousand is, strictly speaking, the final definitive text. Further, these editions are texts of a version of a work, not separate versions. Careful collation would, of course, be necessary to establish what, if any, revisions might have been made in the 'thousands' between I 845 and I882 since Darwin could, theoretically, have had a direct hand in them. We know, for instance, that the Postscript was added to the r 860 edition but was not incorporated into the main text until I 890 .

The Diary presents a different problem. Because Darwin did not intend it for publication in its entirety, but rather as a coherent account of the trip written for the benefit of his family, it fits into what Thorpe categorizes as a 'potential' version of the work. ${ }^{13}$ It was not published until I933 (and again in facsimile in 1979) and at that time became an 'actual' work of art. It does not, however, possess any 'authority,' as Darwin did not himself edit it. What the Diary does provide is a fruitful reference source for the annotation of a critical edition, including the clarification and expansion of specific passages. The notebooks, both those designated 'small' and the large notebooks, could serve the same function.

The questions referred to earlier might now be considered. Which text did Darwin think best? It seems clear (and there is evidence in Darwin's correspondence to substantiate this) that Darwin preferred, as his final work, the editions of his books that he himself revised. There is also considerable evidence that he was a careful and meticulous reviser and proof-reader and the publishing system of Murray's encouraged this trait. The steady 'progression' of a text (dare I say 'evolution'?) is demonstrated by the history of Origin but seems true of the other books as well.

Which text represents Darwin at his best? As in the case of Mill this question is more difficult to answer in a positive way. Great interest may be evoked by the first edition of the Journal of Researches because it is closer in time to the events described and may retain a kind of freshness lost in subsequent editions. It was, on the other hand, composed for publication under the constraints imposed by the other volumes of Captain Fitzroy's Narrative, which have a tendency to aridness. The freshest account, of course, is contained in the Diary. The question is open and requires informed, subjective judgment.

Question number one - which text best represents what Darwin wrote? - 
can be answered in a manner similar to that of the Mill editions. For substantive variants the 1845 edition or, possibly, that of 1860 is to be preferred. For accidentals one could, I think, be satisfied with the 1845 second edition because of the obvious care with which it was revised. Even if changes in punctuation and spelling were made by compositors or house editors, they would have been given tacit approval by Darwin.

On purely textual grounds then it would seem sensible to choose the 1845 second edition, ideally in its original part form (we are dealing here with stereo plates), as copy-text for a critical edition. The editorial task would be to indicate and reproduce the textual changes from the first edition and appropriate passages from the Diary and Notebooks. Cognizance would have to be taken of variants introduced after 1845 . This sounds simple but would be a considerable undertaking.

There are two more major considerations: illustrations and annotation. The first edition of Journal of Researches contained two maps (or, more properly, charts), either in a pocket or inserted, and four text woodcuts. The second edition abandoned the maps, which did not appear again until I890, and increased the number of woodcuts to fourteen. This form remained until the I890 Murray edition, which contained twelve plates, the two maps, and ninety-three text woodcuts. Since then several of the drawings and watercolours made by Fitzroy, Augustus Earle, Conrad Martens, and others during the voyage (Darwin himself was no draughtsman) have been published, most notably by Alan Moorehead in his Darwin and the Beagle. The text of the Journal of Researches cries out for illustrations, and an important editorial decision would have to be made concerning them.

The question of the annotation of literary texts in critical editions is a vexed one. If anything, it is more important for a text such as the Journal of Researches because of the scientific detail that it contains. How much knowledge of natural history, geology, and geography can one assume in a scholarly but general audience? How much of the ultimate significance of Darwin's observations, when viewed in the light of the theory of natural selection, must be explicated? There do exist a number of excellent secondary sources on Darwin and his work to which reference may'be made, but there are also conflicting opinions concerning many facets of his life, for instance, his health. The publication of his Complete Letters, a project now under way, would greatly assist any annotator.

A great deal of the interest in the Journal of Researches focuses on the development of Darwin's evolutionary theories, and one more example will illustrate how useful a scholarly, critical edition of the work could be. Shortly after the Beagle reached the Galapagos Islands Darwin observed, in one of the small notebooks, 'The Thenca very tame and curious in these islands. I certainly recognize S. America in Ornithology - would a botanist? $3 / 4$ of plants in 
flower. ${ }^{14}$ In the Diary, under September 26 th and 27 th, 1835, he writes, 'I industriously collected all the animals, plants, insects and reptiles from this Island. It will be very interesting to find from future comparison to what district or "centre of creation" the organized beings of this archipelago must be attached. ${ }^{15}$ In a 'large notebook' on ornithology the next year he noted, 'These birds are closely allied in appearance to the Thenca of Chile,' and goes on to describe in detail the birds that came to be known as Darwin's Finches. He suspects that differences he noted indicate varieties and concludes, 'If there is the slightest foundation for these remarks, the zoology of archipelagoes will be well worth examining, for such facts would undermine the stability of Species. ${ }^{16}$ In the first edition of the Journal of Researches Darwin is extremely cautious. 'It is clear, that if several islands have each their peculiar species of the same genera, when these are placed together, they will have a wide range of character [he is speaking of finches]. But there is not space in this work, to enter on this curious subject.'17 In the second edition there is much more on the Galapagos and speculation continues: 'Seeing this gradation and diversity of structure in one small, intimately related group of birds, one might really fancy that from an original paucity of birds in this archipelago, one species had been taken and modified for different ends.' ${ }^{18}$

The final general statement, however, was saved for the opening statement of the Origin of Species, and it constitutes, perhaps, the final textual variant in this series:

When on board H.M.S. 'Beagle' as naturalist, I was much struck with certain facts in the distribution of the inhabitants of South America, and in the geological relations of the present to the past inhabitants of that continent. These facts seemed to me to throw some light on the origin of species - that mystery of mysteries, as it has been called by one of our greatest philosophers. ${ }^{19}$

\section{NOTES}

I. The collection is described in a pamphlet by Richard Landon, Species of Origin: $A$ Bibliographical Exposition of the Works of Charles Darwin at the University of Toronto (University of Toronto Library, I97I).

2. Richard B. Freeman, The Works of Charles Darwin: An Annotated Bibliographical Handlist, 2 d ed., rev. and enl. ([London] Dawson [1977]; first published I965). This list includes the holdings of major repositories of Darwin's works, including the Thomas Fisher Rare Book Library.

3. Letter to John Murray, December I860; quoted in The Life and Letters of Charles Darwin (London: John Murray, I887), II: 356.

4. First used in the chapter heading to chapter Iv, Origin ..., 5 th ed. (I869), p. 9I.

5. Origin ..., 6th ed. (1872), pp. 201 and 424.

6. Cf., for instance, Sir Gavin de Beer, Charles Darwin: A Scientific Biography (London: Nelson, 1963), chapter 4.

7. Charles Darwin and the Voyage of the Beagle, ed. with an introd. by Nora Barlow (London: Pilot Press, I945), p. 175. 
8. Charles Darwin, The Journal of a Voyage in H.M.S. Beagle (Guildford: Genesis Publications, I979l, pp. 296-7.

9. Charles Darwin, Journal of Researches ... (London: Henry Colburn, I839), pp. 243-4.

Io. Ibid., pp. 280-I.

II. Charles Darwin, Darwin's Journal of a Voyage round the World, part 2, Murray's Home and Colonial Library, no. xxiII (London: John Murray, I845), pp. 224-5.

12. John M. Robson, 'Principles and Methods in the Collected Edition of John Stuart Mill,' in Editing Nineteenth Century Texts: Papers Given at the Editorial Conference, University of Toronto, November 1966 (Toronto: University of Toronto Press, I967), pp. I I I-8.

13. James Thorpe, Principles of Textual Criticism (San Marino: The Huntington Library, 1972), pp. 187-8.

I4. Barlow, p. 247.

15. Darwin, Journal of a Voyage (1979), p. 6ir.

I6. Quoted by Lady Barlow from one of the Ornithological Notebooks; cf. Barlow, p. 246.

17. Darwin, Journal of Researches (1839), p. 475.

18. Darwin, Journal of a Voyage (I845), p. 380.

I9. Charles Darwin, On the Origin of Species ... (London: John Murray, I859), p. [r]. 